\title{
STAKEHOLDER THEORY AND THE SUSTAINABLE RECOVERY OF THE TOURISM SECTOR
}

\author{
María Elena Silva-Santisteban Mondoñedo* \\ Universidad de La Laguna
}

\begin{abstract}
Stakeholder theory has been applied in the traditional disciplines of business, as well as, in tourism research. This article presents a review of stakeholder theory, putting emphasis on instrumental stakeholder theory, and it presents the application of stakeholder theory to tourism research. It continues with a description of the current situation of the tourism industry and outlines the value of stakeholder theory in the recovery of the tourism sector. It is affirmed that the principles of instrumental stakeholder theory are capable of creating competitive advantage and social welfare. In order to attain both, stakeholder work needs to be performed and stakeholder engagement needs to be undertaken. It is argued that instrumental stakeholder theory might be very helpful for the sustainable recovery of the tourism sector after the pandemic.
\end{abstract}

KEYwORDs: stakeholder theory, tourism sector, sustainability, stakeholder work, stakeholder engagement.

\section{LA TEORÍA DE LAS PARTES INTERESADAS \\ Y LA RECUPERACIÓN SOSTENIBLE \\ DEL SECTOR TURÍSTICO}

\section{RESUMEN}

La teoría de las partes interesadas se ha aplicado en las disciplinas tradicionales de la empresa, así como en la investigación del turismo. Este artículo presenta una revisión de esta teoría, haciendo hincapié en la teoría instrumental. A continuación, presenta la aplicación de la teoría al sector de la investigación turística. Continúa con una descripción de la situación actual de la industria turística y expone el valor de la aplicación de la teoría en la recuperación del sector turístico. Se afirma que los principios de la teoría instrumental son capaces de crear una ventaja competitiva y bienestar social. Para lograrlo, es necesario desarrollar stakeholder work y llevar a cabo stakeholder engagement. Se argumenta que esta teoría puede ser muy útil para la recuperación sostenible del sector turístico tras la pandemia.

PALABRAS ClAVE: teoría de las partes interesadas, sector turístico, sostenibilidad, stakeholder work, stakeholder engagement. 


\section{INTRODUCTION}

Stakeholder theory has been developed during the last 40 years and it has been applied in the traditional disciplines of business such as strategic management, business ethics, finance, accounting, and marketing, as well as, in related disciplines such as law, public administration, health care and environmental policy (Freeman, Harrison, Wicks, Parmar and De Colle, 2010). Stakeholder theory is regarded to be the main opponent to the shareholder model which is based on ownership and on the idea that shareholders are entitled to the residual gainings that arise from value creation (Freeman et al., 2010; Friedman and Miles, 2006). The concept of stakeholder was meant to enlarge the notion of shareholder as the only group to whom management owed a responsibility for their actions (Freeman et al., 2010). Stakeholder theory tries to explain how business could be understood against the background of environmental turbulence and change in business relationships (Freeman et al., 2010).

In the tourism sector there is a wide range of actors which are highly interdependent and it is proposed that instrumental stakeholder theory is capable and likely to provide a sustainable competitive advantage to firms applying its principles. Furthermore, the application of instrumental stakeholder theory will contribute to the development of a close relationship capability, which is likely to be a source of competitive advantage (Jones, Harrison and Felps, 2018). Also, environmental dynamism and the reciprocal interdependence of tourism stakeholders will increment the benefits of this type of relationship (Jones et al., 2018). Moreover, it is contended that companies that practice management based on instrumental stakeholder theory principles may potentially enhance shareholder welfare and social welfare simultaneously and that managers should take into consideration the creation of wealth for all their stakeholders, not only of shareholders or of the owners of businesses, and that losses incurred by any stakeholder need to be mitigated in order to ensure the sustainability of the economy (Jones and Harrison, 2019).

The current health crisis and its effects on the economy urge us to find new ways to tackle the situation in the tourism sector, especially, in destinations which are dependent on this sector. Further, the current situation offers a good opportunity to test the applicability and usefulness of stakeholder theory, in particular, instrumental stakeholder theory. It is believed that the application of instrumental stakeholder theory will positively impact and support the recovery of the tourism sector. The next sections will present the literature review on stakeholder theory, as well as, its application to the tourism sector.

*E-mail: alu0100737905@ull.edu.es. Doctoranda en Derecho, Sociedad y Turismo, Universidad de La Laguna. 


\section{LITERATURE REVIEW}

A stakeholder is defined by Freeman (1984, p. 46) as “... any group or individual who can affect or is affected by the achievement of the organization's objectives." In the subsequent years many authors have developed other definitions, some of them with a narrow and others with a broader scope (Mitchell, Agle and Wood, 1997) ${ }^{1}$. Narrow views of stakeholders define stakeholders according to their direct relevance to the organization's main economic interests, whereas broad views of stakeholders are based on the fact that organizations can be affected by, or they can affect, almost anyone (Mitchell et al., 1997). Nonetheless, Freeman et al. (2010) considered the debate about the "right definition" of a stakeholder not useful and pointed out that the purpose of using any proposed definition needs to be clear.

There are five common groups of stakeholders considered to be primary stakeholders, namely: shareholders or financiers, customers, suppliers, employees and communities (Freeman et al., 2010; Friedman and Miles, 2006). A primary stakeholder is one without whose continuing participation the firm cannot survive, whereas secondary stakeholders are those who influence or affect, or are influenced or affected by, the firm (Clarkson, 1995). Depending on the nature of the firm and its industry there are other stakeholders called secondary stakeholders which include the government, non-governmental organizations, competitors, consumer advocate groups, special interest groups, unions and the media (Freeman et al., 2010; Freeman, Harrison and Zyglidopoulos, 2018). The next section will present the differences between stakeholder and shareholder theory.

\section{STAKEHOLDER AND SHAREHOLDER THEORY}

Stakeholder theory should not be regarded as a specific theory with a single purpose, rather, it is a set of shared ideas that can address different questions within different disciples (Freeman et al., 2010). A shared sense of purpose among stakeholders helps accomplishing the aim of a stakeholder approach which is defined as: "a stakeholder approach to business is about creating as much value as possible for stakeholders, without resorting to trade-offs" (Freeman et al., 2010, p. 28). Stakeholder interests need to be seen as joint interests and when the interests conflict and trade-offs have to be made, the trade-offs need to be improved immediately for all sides (Freeman et al., 2010).

Stakeholder theory has been developed (I) to tackle the problem of value creation and trade in turbulent business environments; (II) to understand the ethics of capitalism, and (III) to solve the problem of managerial mindset (Freeman et al., 2010). The problem of value creation and trade referred to the idea that values and ethics in a business context were irrelevant, which created the problem of the

\footnotetext{
${ }^{1}$ See Mitchell, Agle and Wood (1997) for a comprehensive list of definitions of stakeholders.
} 
ethics of capitalism (Freeman et al., 2010). Capitalism restricted attention to the economic effects of value creation and trade which only provided a partial view of reality and divided the world into the business field and the ethical field (Freeman et al., 2010). The problem of managerial mindset arose from the two former ones in that the managerial mindset about business was not appropriate for turbulent and changing business environments and in that it divided economics from ethics (Freeman et al., 2010).

Stakeholder theory is regarded to be the main opponent to the stockholder or shareholder model. This model was proposed by Friedman (1962) on the idea that shareholders are entitled to the residual gainings that arise from value creation since shareholders are the owners of the company and, therefore, the duty of management is solely to them (Friedman, (1962), in Freeman et al., 2010; Friedman and Miles, 2006). According to the stockholder model, "the objective of the corporation is to maximize stockholder value expressed either as maximizing long-run profits, growth, or dividends..." (Friedman and Miles, 2006, p. 3). Stakeholder theory recognizes the importance of stockholders, however, it contends that there are also others stakeholders which are important to running a successful business (Freeman et al., 2010). Friedman (1962) believed that the maximization of profits is what makes a business successful while stakeholder theorists argued that solid stakeholder relationships are the fundamental drivers of value (Friedman, (1962), in Freeman et al., 2010). For stakeholder theorists profit maximization is very important, however, they argue that profit maximization should be rather regarded as a result of valuable stakeholder relationships (Freeman et al., 2010). Therefore, it could be said that the main difference between both views is what is considered to make a business successful: for Friedman it is maximizing profits, for stakeholder theorists it is valuable stakeholder relationships which will lead to profit maximization (Freeman et al., 2010). Friedman provided a theory about the way markets work under certain conditions (Agle et al., 2008). In contrast, stakeholder theory is not a theory of the firm, rather, it is a theory about what good management is and about how people create value for each other (Agle et al., 2008).

As stakeholder theory has been developed during the last 40 years, it seems appropriate to present its evolution in order to fully understand it. Thus, the next section deals with the theory's evolution.

\section{EVOLUTION OF STAKEHOLDER THEORY}

In order to fully understand stakeholder theory, it is necessary to be aware of the classification into three streams made by some authors in the 90s. Hill and Jones (1992), Donaldson and Preston (1995) and Jones and Wicks (1999) presented three very influential articles explaining the different streams. Hill and Jones (1992) developed a descriptive stakeholder theory by considering the firm to be a nexus of implicit and explicit contracts among all stakeholders. They gave managers special consideration due to their powerful situation and because they were expected to act as agents of all other stakeholders (Hill and Jones 1992). Further, Donaldson 
and Preston (1995) were the first theorists to classify stakeholder theory into three different streams. They rejected the idea that a single theory is universally applicable and, therefore, presented three different types of stakeholder theory, namely: descriptive/empirical, instrumental and normative. Descriptive/empirical theory is aimed to describe and/or explain how firms or their managers actually behave (Donaldson and Preston, 1995). Instrumental theory intends to describe what will happen if firms or managers behave in certain ways and normative theory deals with the moral correctness of the behaviour of firms and/or their managers (Donaldson and Preston, 1995). With this distinction, they provided a more focused theory with the ability to guide managers in the day-to-day operations, thus, pointing out that stakeholder theory was also managerial. The authors argued that the central core of stakeholder theory is the normative branch and that the other parts of the theory are secondary and concluded that stakeholder theory is a moral theory that determine the obligations that companies have to their stakeholders (Donaldson and Preston, 1995).

In 1999, Jones and Wicks proposed a convergent stakeholder theory. It was a theory of relationships, rather than "contracts", and was simultaneously normative and instrumental. Its normative foundation was moral in nature and the instrumental means-ends chain demonstrated the adequacy of the behaviour supported by its normative core (Jones and Wicks, 1999). This theory aimed to determine the types of stakeholder relationships which were morally sound and practicable at the same time. The authors argued that their convergent stakeholder theory met the standards of integration in some cases, specifically the standards of theoretical reciprocity, which requires "that both normative and empirical theories be incorporated into the explanatory framework" (Jones and Wicks, 1999, p. 12). It involved applying instrumental theory to normative cores to see if they result in viable outcomes, therefore, instrumental theory helped evaluate the practicability of the normative core of the convergent theory (Jones and Wicks, 1999). Convergent stakeholder theory was a new way of theorizing about organizations and was, therefore, transformational. It showed managers how to behave morally in a stakeholder context and how to create moral business environments and, at the same time, ensuring the viability of the firm. The authors underlined the fact that firms with a good reputation for trustworthy and cooperative behaviour will gain competitive advantage.

Furthermore, Donaldson and Preston (1995) and Freeman et al. (2010) agreed on the fact that stakeholder theory is also managerial as it tells managers how to combine business and ethics in order to create as much value as possible for all stakeholders. However, McVea and Freeman (2005) pointed out that stakeholder theory has had a great effect on academics and theorists, but that its influence on practitioners has been rather moderate due to the fact that research has been moving away from real day-to-day challenges faced by managers and entrepreneurs.

Nonetheless, Freeman (1999) disagreed with Jones and Wicks (1999) and refused the idea that a sharp distinction can be made between the three branches of stakeholder theory and, thus, argued that a convergent stakeholder theory is not needed. Instead, more instrumental theories are needed showing different ways to understand organizations in stakeholder terms. Further, he argued that 
the Donaldson-Preston tripartite typology was not appropriate as the separation of contributions supported the separation thesis. The separation thesis postulates that: "The discourse of business and the discourse of ethics can be separated so that sentences like " $\mathrm{x}$ is a business decision" have no moral content, and " $\mathrm{x}$ is a moral decision" have no business content" (Freeman, [1994, p. 412], as stated in Freeman et al., 2010).

The above presented articles led to the development of a number of different types of stakeholder theories which will be presented in the next sections.

\section{DESCRIPTIVE, NORMATIVE AND INSTRUMENTAL STAKEHOLDER THEORY}

This section is divided in three parts, namely: descriptive, normative and instrumental stakeholder theory. First, it will present descriptive stakeholder theory, it will then continue with normative stakeholder theory and it will end with the section on instrumental stakeholder theory.

\section{Descriptive stakeholder theory}

Descriptive or empirical stakeholder theory has not been widely analyzed or developed by many academics. The most prominent contributions on descriptive stakeholder theory have been elaborated by Hill and Jones (1992) and by Jawahar and McLaughlin (2001). Hill and Jones (1992) considered the firm to be a nexus of implicit and explicit contracts among all stakeholders and rejected the supposition that firms operate in efficient markets, i.e. being able to adjust rapidly to changes and new situations (Hill and Jones, 1992). In their contribution, the authors only considered legitimate stakeholders and gave managers special consideration due to their powerful situation in comparison with other stakeholders and as they were expected to act as agents of all other stakeholders (Hill and Jones, 1992). Jawahar and McLaughlin (2001) integrated theory on resource dependence theory, prospect theory, and organizational life cycle models to develop their descriptive stakeholder theory. They based their theory on the assumption that firms face different threats and pressures at different stages in the organizational life cycle and, therefore, different stakeholders become critical for organizational survival at different stages of the life cycle. Thus, depending on who the critical stakeholders are at each stage, organizations are likely to use different strategies to deal with those critical stakeholders (Jawahar and McLaughlin, 2001). 


\begin{tabular}{|c|c|c|c|}
\hline & $\begin{array}{l}\text { MODEST THEORIES } \\
\text { (claims, e.g., that } \\
\text { stakeholders should be } \\
\text { treated with respect) }\end{array}$ & $\begin{array}{l}\text { INTERMEDIATE } \\
\text { THEORIES } \\
\text { (incorporating some } \\
\text { stakeholder interests in } \\
\text { the governance of the } \\
\text { corporation) }\end{array}$ & $\begin{array}{l}\text { DEMANDING THEORIES } \\
\text { (claiming participation } \\
\text { for all stakeholders } \\
\text { in corporate decision } \\
\text { processes) }\end{array}$ \\
\hline $\begin{array}{l}\text { THEORIES OF THE } \\
\text { FIRST KIND } \\
\text { (concerned with the } \\
\text { characteristics of an } \\
\text { ideal just society) }\end{array}$ & & & $\begin{array}{l}\text { Philosophical literature- } \\
\text { Rawlsian type theories } \\
\text { (Freeman and Evan, } \\
\text { Bowie, Phillips) }\end{array}$ \\
\hline $\begin{array}{l}\text { THEORIES OF THE } \\
\text { SECOND KIND } \\
\text { (concerned with morally } \\
\text { desirable legal and } \\
\text { institutional changes) }\end{array}$ & & $\begin{array}{l}\text { Public policy debate } \\
\text { (e.g. Dodd vs. } \\
\text { Berle, Boatright vs. } \\
\text { Williamson) }\end{array}$ & $\begin{array}{l}\text { Philosophical literature- } \\
\text { Pragmatic and feminist } \\
\text { theories (e.g. Freeman } \\
\text { and associates, Burton } \\
\text { and Dunn) }\end{array}$ \\
\hline $\begin{array}{l}\text { THEORIES OF THE } \\
\text { THIRD KIND } \\
\text { (concerned with morally } \\
\text { desirable management } \\
\text { behaviour in the context } \\
\text { of existing laws and } \\
\text { institutions) }\end{array}$ & $\begin{array}{l}\text { Management literature } \\
\text { (e.g. Donaldson and } \\
\text { Preston, Jones and } \\
\text { Wicks) }\end{array}$ & & \\
\hline
\end{tabular}

\section{Normative stakeholder theory}

There is a vast number of normative stakeholder theories and Hendry (2001) attempted to provide an overview of the field by distinguishing three kinds of normative stakeholder theories and three levels of claims that can be made by such theories. Table I presents his classification of normative stakeholder theories.

Hendry (2001) explained that theories of the first kind propose that an ideal society business should be managed for the benefit of stakeholders. Theories of the second kind go further and require changes in the laws and institutions to ensure greater corporate responsibility towards stakeholders (Hendry, 2001). Finally, theories of the third kind proposed that managers should consider the interests of all stakeholders in the firm given the existing institutional and legal environment (Hendry, 2001). Hendry (2001) further differentiated between the level of claims with reference to the nature and extent of the firm's responsibility to stakeholders, namely, modest, intermediate and demanding. Finally, he concluded recommending the development of theories of the second kind and intermediate theories to inform the public policy debate.

Taking Hendry's model as a basic framework, Friedman and Miles (2006) presented a different classification of normative stakeholder theories (see table II).

Friedman and Miles (2006) complemented the label "kinds of theory" with the concept of futurity. The authors viewed the three kinds of theories as points 


\begin{tabular}{|c|c|c|c|c|}
\hline \multicolumn{5}{|c|}{$\begin{array}{l}\text { TABLE II. CLASSIFICATION OF NORMATIVE STAKEHOLDER } \\
\text { THEORIES (FRIEDMAN AND MILES, 2006) }\end{array}$} \\
\hline & \multirow{2}{*}{\multicolumn{2}{|c|}{$\begin{array}{l}\text { KIND OF THEORY } \\
\text { MANAGERS }\end{array}$}} & \multicolumn{2}{|c|}{$\begin{array}{c}\text { AgENCY } \\
\text { CONCERNED WITH THE ETHICAL BEHAVIOUR OF: }\end{array}$} \\
\hline & & & Managers & STAKEHOLDERS \\
\hline \multirow{6}{*}{ 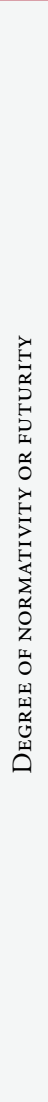 } & \multirow[b]{2}{*}{$\begin{array}{l}\text { First kind: } \\
\text { ideal just } \\
\text { society }\end{array}$} & $\begin{array}{l}\text { 1a Total just society } \\
\text { idealizations }\end{array}$ & $\begin{array}{l}\text { Ecology: } \\
\text { - Starik (1994) }\end{array}$ & \\
\hline & & $\begin{array}{l}\text { 1b Constrained } \\
\text { just society } \\
\text { idealizations }\end{array}$ & $\begin{array}{l}\text { Kantian: } \\
\text { - Evan and Freeman (1993) } \\
\text { - Bowie (1998) } \\
\text { Rawlsian: } \\
\text { - Phillips (1997) } \\
\text { - Freeman (1994, 2004) } \\
\text { Common good: } \\
\text { - Argandońa (1998) }\end{array}$ & $\begin{array}{l}\text { Social contracts theory: } \\
\text { - Donaldson and Dunfee } \\
(1994,1999)\end{array}$ \\
\hline & \multirow{2}{*}{$\begin{array}{l}\text { Second kind: } \\
\text { laws and } \\
\text { institutions }\end{array}$} & $\begin{array}{l}\text { 2a Reflect growing } \\
\text { minority ideals, } \\
\text { or reflect the } \\
\text { direction in which } \\
\text { current society is } \\
\text { evolving }\end{array}$ & $\begin{array}{l}\text { Feminist: } \\
\text { - Wicks, Gilbert and } \\
\text { Freeman (1994) } \\
\text { - Burton and Dunn (1996) }\end{array}$ & $\begin{array}{l}\text { Postmodern: } \\
\text { - Calton and Kurland } \\
\text { (1995) }\end{array}$ \\
\hline & & $\begin{array}{l}\text { 2b Reflect legal/ } \\
\text { institutions in } \\
\text { other societies or } \\
\text { past forms }\end{array}$ & \multicolumn{2}{|l|}{$\begin{array}{l}\text { - Dodd (1932) } \\
\text { Stakeholders as investors: } \\
\text { - Schlossberger (1994) } \\
\text { - Etzioni (1996, 1998) } \\
\text { - Blair (1998) }\end{array}$} \\
\hline & \multirow[b]{2}{*}{$\begin{array}{l}\text { Third kind: } \\
\text { corporate } \\
\text { response }\end{array}$} & \multirow[b]{2}{*}{$\begin{array}{l}3 \text { Identify to whom } \\
\text { and for what } \\
\text { managers are } \\
\text { morally responsible } \\
\text { given the } \\
\text { contemporary legal } \\
\text { and institutional } \\
\text { context }\end{array}$} & - Jones and Wicks (1999a) & \\
\hline & & & $\begin{array}{l}\text { Fiduciary relationships: } \\
\text { - Boatright (1994) } \\
\text { - Goodpaster (1991) } \\
\text { Property rights: } \\
\text { - Donaldson and Preston } \\
\quad \text { (1995) } \\
\text { Aristotelian: } \\
\text { - Wijnberg (2000) }\end{array}$ & \\
\hline
\end{tabular}

along a dimension of logical time or futurity or of normativity or idealism. They differentiated them based on the extent to which current laws and institutions must be changed in order to achieve what the theories consider to be an appropriate relationship between stakeholders and managers (Friedman and Miles, 2006). According to Friedman and Miles (2006), theories of the third kind are immediately achievable, theories of the second kind are less achievable, and theories of the first kind are idealized and, thus, unachievable in the near future. A discussion of the above presented normative stakeholder theories is beyond the scope of this research paper, however, a full discussion can be found in Friedman and Miles (2006). 
It is claimed that instrumental stakeholder theory is likely to contribute to sustainable competitive advantage. Jones, Harrison and Felps (2018) explained this idea and elaborated that a close relationship capability has a number of benefits and that it is valuable since it is likely to be a source of sustainable competitive advantage.

Jones et al. (2018) examined the question why the ethical provisions of instrumental stakeholder theory are not the dominant mode of firm/stakeholder relationships. They argued that existing instrumental stakeholder theory research has three substantial weaknesses that limit its usefulness. First, although all instrumental stakeholder theory-based studies defend that particular ethical practices are valuable, they fail to describe them to be rare or difficult to imitate. Peteraf and Barney (2003), as cited in Jones et al. (2018, p. 2), defined sustainable competitive advantage as "a firm's ability to persistently create more economic value than the marginal (breakeven) competitor in its product market." Furthermore, the costs of adopting the proposed ethical practices of instrumental stakeholder theory have been insufficiently explored. Lastly, few studies have taken into account the competitive context in which a firm operates as relevant to instrumental stakeholder theorypredicted performance outcomes.

Jones et al. (2018) examined how and under what circumstances a stakeholder management strategy, based on the ethical norms associated with instrumental stakeholder theory, is likely to contribute to sustainable competitive advantage. According to the authors, firms adopting a relational ethics strategy consistent with communal sharing relationships are able to develop a close relationship capability. A close relationship capability is potentially valuable as it has the following benefits: "improved reciprocal coordination, better knowledge sharing, attraction of higherquality stakeholders, lower transaction costs, and greater moral motivation" (Jones et al., 2018, p. 14). Environmental dynamism, knowledge intensity, and reciprocal interdependence with stakeholders will increment the benefits of a close relationship capability. However, it also bears some costs including non-reciprocation by stakeholders, excessive allocation of jointly created value, and unprofitable loyalty of some stakeholders. The costs will vary depending on the firm's overall ethical culture, they will be higher if the ethical culture is more self-regarding than otherregarding. The authors concluded that a close relationship capability will be rare, difficult to imitate and, therefore, likely to be a source of sustainable competitive advantage.

Jones and Harrison (2019) proposed a new corporate objective that helps firms achieve improved profitability and simultaneously enhances social welfare through their economic activities, in this way, achieving sustainable wealth creation and supporting the responsible and sustainable recovery of the tourism industry.

Jones and Harrison (2019) explored the notion that companies that practice management based on instrumental stakeholder theory principles may potentially enhance shareholder welfare and social welfare at the same time. Jones et al. (2016, p. 220) defined social welfare as "... the well-being of a society as a whole, encompassing economic, social, physical, and spiritual health." The authors preferred 
this definition instead of the narrow definition of social welfare (government programs providing assistance to poor families) since they assess social welfare more broadly. Referring to the work of Adam Smith (the invisible hand) and Michael Jensen (enlightened stakeholder theory), the authors pointed out that profit seeking and market value maximization are both means to enhance social welfare. However, corporate profit maximization may in some cases lead to decreases in social welfare and, therefore, they proposed a modified single-valued objective in order to maximize social welfare. According to Jones and Harrison (2019, p. 82), "the objective of the firm should be to maximize the wealth of corporate shareholders without making any other stakeholders worse off." Thus, they proposed a new corporate objective that helps firms achieve improved profitability and simultaneously enhances social welfare through their economic activities, in this way achieving sustainable wealth creation. They suggested that by making Pareto improvements the firm should increase shareholders' wealth without reducing, and whenever possible, increasing the aggregate wealth of its other stakeholders. Jones and Harrison (2019, p. 84) defined Pareto improvements as "... exchanges wherein one (or more) parties is (are) made better off without making any other party (parties) worse off", thus, generating always a net gain for either party and enhancing social welfare. They argued that managers should take into consideration the creation of wealth for all their stakeholders, not only shareholders, and that losses incurred by any stakeholders need to be mitigated in order to ensure the sustainability of the economy.

Mitchell and Lee (2019) studied the importance of value creation for all stakeholders which is crucial for an equal and sustainable recovery of the tourism sector and Greenwood (2007) underlined the importance of stakeholder engagement in order to implement an effective strategy.

Mitchell and Lee (2019) studied stakeholder identification and its importance on the objective of value creation. Mitchell and Lee (2019) adopted the following definition of value creation as found in Freeman et al. (2010, p. 11):

Business [value creation] is about making sure that products and services actually do what you say they are going to do, doing business with suppliers who want to make you better, having employees who are engaged in their work, and being good citizens in the community, all of which may well be in the long-run (or even possibly the short-run) interest of a corporation.

It can be therefore said that value creation by firms specifically comprises at least "quality and customer service, supplier relationships, employee enrichment, community benefit and stockholder reward (Freeman et al., 2010, p. 11)."

Mitchell and Lee (2019) stated that Clarkson (1995) identified stakeholders as primary and secondary stakeholders, however, that this approach focused on explaining stakeholder importance to firm survival and not on the objective of value creation. Further, Mitchell's et al. (1997) proposed attributes-based approach based on stakeholder's levels of power, legitimacy, and urgency in stakeholder relationships does not explain how the different stakeholder types resulting from this analysis connect to value creation. Mitchell and Lee (2019) argued that most stakeholder identification mechanisms do not explain what leads to value creation and pointed 


\begin{tabular}{|c|c|c|}
\hline \multicolumn{3}{|c|}{$\begin{array}{l}\text { TABLE III. STAKEHOLDER WORK BASED ON LEE (2015), } \\
\text { AS PRESENTED IN MITCHELL AND LEE (2019) }\end{array}$} \\
\hline Phases & DEFINITION & Actions \\
\hline $\begin{array}{l}\text { Stakeholder } \\
\text { Awareness } \\
\text { Work }\end{array}$ & $\begin{array}{l}\text { Organizing activities aimed } \\
\text { at evaluating stakeholders' } \\
\text { action and/or potential action } \\
\text { toward a given organization }\end{array}$ & $\begin{array}{l}\text { - Paying attention to the social environment } \\
\text { - Managers pay attention to the socioeconomic } \\
\text { environment surrounding the organization and } \\
\text { understanding the competitive landscape } \\
\text { - Managers gather information about potential and } \\
\text { actual stakeholders } \\
\text { - Managers study how stakeholders exert influence on } \\
\text { the organization itself }\end{array}$ \\
\hline $\begin{array}{l}\text { Stakeholder } \\
\text { Identification } \\
\text { Work }\end{array}$ & $\begin{array}{l}\text { Organizing activities aimed at } \\
\text { recognizing stakeholders who } \\
\text { matter (to value creation) for a } \\
\text { given organization }\end{array}$ & $\begin{array}{l}\text { - Concentrates managers' attention on the } \\
\text { stakeholders who will be included in the work of } \\
\text { value creation }\end{array}$ \\
\hline $\begin{array}{l}\text { Stakeholder } \\
\text { Understanding } \\
\text { Work }\end{array}$ & $\begin{array}{l}\text { Organizing activities aimed at } \\
\text { knowing the needs and desires } \\
\text { of stakeholders of a given } \\
\text { organization }\end{array}$ & $\begin{array}{l}\text { - Research on corporate social responsibility } \\
\text { - Research on corporate citizenship } \\
\text { - Attention to the potential gap between what } \\
\text { stakeholders need and what an organization delivers }\end{array}$ \\
\hline $\begin{array}{l}\text { Stakeholder } \\
\text { Prioritization } \\
\text { Work }\end{array}$ & $\begin{array}{l}\text { Organizing activities aimed } \\
\text { at prioritizing competing } \\
\text { stakeholder claims with } \\
\text { respect to a given organization }\end{array}$ & $\begin{array}{l}\text { - Examination of stakeholder attributes associated } \\
\text { with stakeholder prioritization: power, legitimacy, } \\
\text { urgency (Mitchell et al. 1997); proximity (Driscoll } \\
\text { and Starik 2004); various types of power (Eesley } \\
\text { and Lenox 2006); powerlessness and illegitimacy } \\
\text { (Weitzner and Deutsch 2015) }\end{array}$ \\
\hline $\begin{array}{l}\text { Stakeholder } \\
\text { Engagement } \\
\text { Work }\end{array}$ & $\begin{array}{l}\text { Organizing activities aimed } \\
\text { at taking action with respect } \\
\text { to the stakeholders of a given } \\
\text { organization }\end{array}$ & $\begin{array}{l}\text { - Leads to value creation through support from } \\
\text { stakeholders } \\
\text { - Actions leading to support: building trust rather } \\
\text { than treating stakeholders opportunistically (Jones } \\
\text { 1995); charitable efforts of the organization (Adams } \\
\text { and Hardwick 1998; Brammer and Millington } \\
\text { 2003a, 2003b; Godfrey 2005); employee stock } \\
\text { option programs (Marens and Wicks 1999); } \\
\text { reputation management, impression management, } \\
\text { rhetoric, strategic use of images (Carter 2006, } \\
\text { Snider, Hill and Martin 2003, Ulmer and Sellnow } \\
\text { 2000); more effective identification of stakeholders } \\
\text { by the organization (Scott and Lane 2000) }\end{array}$ \\
\hline
\end{tabular}

out that Barney's (2018) proposition, namely, that stakeholder groups beyond shareholders are important because they provide resources to a firm in return for some compensation and are hence entitled to some distribution of expected economic profits, connects rather stakeholder identification to creating value. The authors affirmed that stakeholder identification work is only one phase in creating value, one step of five, that comprises the overall system of stakeholder work. Table III presents a summary of the stakeholder work system.

Stakeholder work is defined as: "The purposive processes or organization aimed at being aware of identifying, understanding, prioritizing, and engaging stakeholders (Lee, 2015, p. 12), as stated in Mitchell and Lee 2019).” The stakeholder 


\begin{tabular}{|c|c|c|c|c|}
\hline \multicolumn{5}{|c|}{$\begin{array}{l}\text { TABLE IV. TOWARD STAKEHOLDER ENGAGEMENT: THE STAKEHOI } \\
\text { VALUE CREATION SYSTEM (MITCHELL ET AL. (2015), } \\
\text { AS PRESENTED IN MITCHELL AND LEE, 2019) }\end{array}$} \\
\hline & Phase 1 & Phase 2 & Phase 3 & Phase 4 \\
\hline $\begin{array}{l}\text { Value Creation } \\
\text { Premises }\end{array}$ & Activities Premise & Alignment Premise & Interaction Premise & Reciprocity Premise \\
\hline Stakeholder Work & $\begin{array}{l}\text { Stakeholder } \\
\text { Awareness Work }\end{array}$ & $\begin{array}{l}\text { Stakeholder } \\
\text { Identification Work }\end{array}$ & $\begin{array}{l}\text { Stakeholder } \\
\text { Understanding } \\
\text { Work }\end{array}$ & $\begin{array}{l}\text { Stakeholder } \\
\text { Prioritization Work }\end{array}$ \\
\hline \multicolumn{5}{|c|}{$\rightarrow$ Leading to Stakeholder Engagement Work (Phase 5) } \\
\hline
\end{tabular}

work system includes five distinct phases which correspond to the temporal phases in stakeholder relationships that lead to value creation, namely: stakeholder awareness work, stakeholder identification work, stakeholder understanding work, stakeholder prioritization work, and stakeholder engagement work (Lee, (2015), as stated in Mitchell and Lee 2019). Lee (2015), as explained in Mitchell and Lee (2019), was the first offering a completely operationalized theoretical explanation of value creation through stakeholder engagement in the strategic management context.

Mitchell and Lee (2019) affirmed that the five phases of stakeholder work support each other to result in value creation and termed this mutual support consonance. They defined stakeholder work consonance as: "the ongoing adjustment among the various temporal phases/subsystems of stakeholder work to enable the inclusion and integration of the stakeholders necessary for value creation (Mitchell and Lee, 2019, p. 61)." It follows that there needs to be a dynamic and intersupportive interplay a mong various phases of stakeholder work in order to create value (Mitchell and Lee 2019). Further, consonance across phases can increase the effectiveness of stakeholder engagement which in turn results in value creation (Mitchell and Lee 2019).

Mitchell, Van Buren, Greenwood and Freeman (2015) articulated a value creation process with four value creation premises that require consonance and that are linked with the phases of stakeholder work proposed by Lee (2015) and pointed out that effective stakeholder identification enables alignment in value creation and, therefore, it supports stakeholder engagement and effective value creation (see table IV).

Finally, they defined value creating stakeholder engagement as: "the pursuit of value-creation activities with stakeholders (Mitchell and Lee, 2019, p. 62)" and argued that without the stakeholder identification work, value creating stakeholder engagement is compromised and, thus, the stakeholder work as a system of value creation is less effective.

Greenwood (2007, p. 317) defined stakeholder engagement as "practices that the organisation undertakes to involve stakeholders in a positive manner in organisational activities." Hence, it can be said that many areas of organisational activity involve stakeholder engagement, for example, customer service, human 


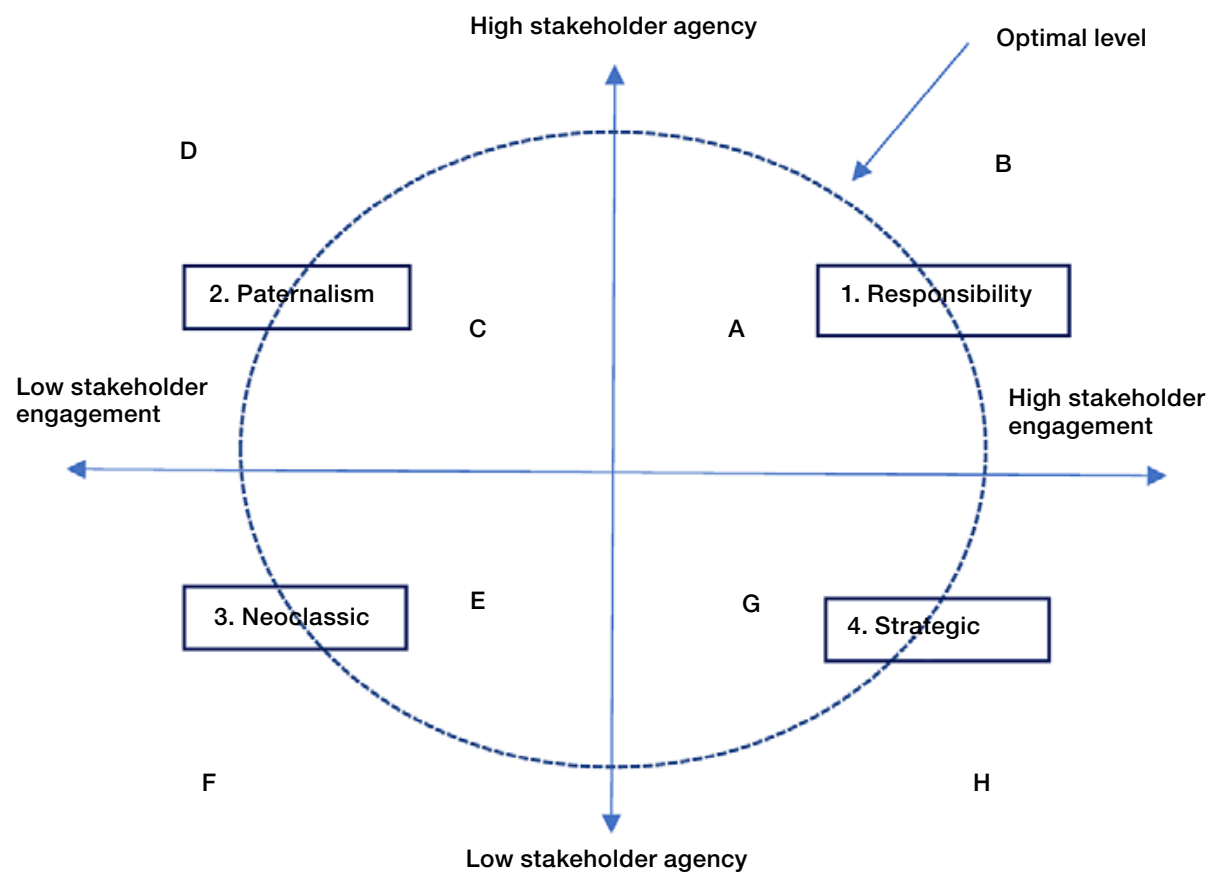

Figure 1. A model of stakeholder engagement and the moral treatment of stakeholders (Greenwood, 2007).

resource management and supplier relations. Stakeholder engagement per se is not directly linked to the responsible treatment of stakeholders, it may coincide with the moral treatment of stakeholders, but it also may run counter to moral behaviour (Greenwood, 2007). Greenwood (2007) argued that stakeholder engagement is a morally neutral practice which does not mean that it is without moral value. The stakeholder engagement process should be considered as independent of the intentions of the actors, the virtue of the actors and the fairness of the outcomes, therefore, it can be described as morally neutral as opposed to amoral or value-free. Further, stakeholder engagement can be used in a moral or in an immoral way specially when disguised as corporate responsibility. Corporate responsibility is defined as "the responsibility of the corporation to act in the interests of legitimate organisational stakeholders" (Greenwood, 2007, p. 315) and it forms the foundations of stakeholder theory. The responsible treatment of stakeholders has been defined as "the organisation acting in the interests of legitimate stakeholders" (Greenwood, 2007, p. 320). Greenwood (2007) presented a model which explored the relationship between stakeholder engagement and stakeholder agency (see figure 1).

The $\mathrm{x}$-axis of the model is labelled Stakeholder Engagement which is a process of consultation communication, dialogue and exchange. The $y$-axis of the 
model is labelled Stakeholder Agency which is a proxy for the responsible treatment of stakeholders. Specifically, stakeholder agency is the number and breadth of stakeholder groups in whose interest the organization acts. Single stakeholder consideration is where the organization considers one or a small number of stakeholders whereas multiple stakeholder consideration is where the organization considers a larger number and/or a broader range of stakeholders. Greenwood's model of stakeholder engagement and the moral treatment of stakeholders is divided into four quadrants and eight segments as described in table v.

Greenwood (2007) underlined the fact that practicing stakeholder engagement but, at the same time, disregarding stakeholders' interests is equivalent to deception and manipulation of stakeholders and that her model offered a beginning of the development of a theoretical understanding of corporate irresponsibility. She concluded that it is likely that the segments will overlap and that both axes are continua and, therefore, each quadrant should also be regarded as a continuum. Hence, an organisation will have different engagement types across different business units and over time.

Noland and Phillips (2010) argued that interaction with stakeholders is a necessary activity of business but that interaction alone is not sufficient. They pointed out that engagement is needed which is "... a type of interaction that involves, at minimum, recognition and respect of common humanity and the ways in which the actions of each may affect the other (Noland and Phillips, 2010, p. 40). Freeman et al. (2007) argued that ethical engagement of stakeholders ought to be part of a firm's strategy because unethical practices endanger firm's success. Further, since the purpose of any business is the creation of value for all stakeholders, ethical engagement is necessary for a firm to function properly. Stakeholder engagement (listening to and consulting with stakeholders) facilitates an honest and unfiltered flow of information between stakeholders which is key to effective strategy and, at the same time, it is key to ethical decision making (McVea and Freeman, (2005), in Noland and Phillips, 2010).

The author acknowledges the importance of the above presented descriptive and normative stakeholder theories, however, in this article the author takes the position of Freeman (1999) and argues that more instrumental theories are needed capable to adapt to different organizations and changing circumstances.

The next section will present the application of stakeholder theory to tourism research.

\section{STAKEHOLDER THEORY APPLIED TO TOURISM RESEARCH}

Leiper (1979), as cited in Theodoulidis, Diaz, Crotto and Rancati (2017, p. 174), defined the tourism sector as all organisations that are designed to "serve the specific needs and wants of tourists" and divided the tourism-related industries into the following six segments: tourist carriers, tourist attractions, tourist accommodation, tourist services, tourism marketing and tourism regulators. 


\begin{tabular}{|c|c|c|c|c|c|}
\hline QUADRANTS & Description & Segments & $\begin{array}{l}\text { STAKEHOLDER } \\
\text { ENGAGEMENT }\end{array}$ & $\begin{array}{c}\text { STAKEHOLDER } \\
\text { AGENCY }\end{array}$ & $\begin{array}{l}\text { RELATIONSHIP BETWEEN } \\
\text { STAKEHOLDER ENGAGE- } \\
\text { MENT AND STAKEHOLDER } \\
\text { AGENCY }\end{array}$ \\
\hline \multirow{2}{*}{ 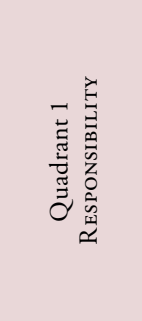 } & \multirow{2}{*}{$\begin{array}{l}\text { Where stakeholder } \\
\text { engagement } \\
\text { combines with } \\
\text { high stakeholder } \\
\text { engagement } \\
\text { we can refer } \\
\text { to corporate } \\
\text { responsibility. }\end{array}$} & $\begin{array}{l}\text { A. } \\
\text { Responsibility } \\
\text { (traditional } \\
\text { corporate social } \\
\text { responsibility) }\end{array}$ & $\begin{array}{l}\text { Comprehensive } \\
\text { engagement of } \\
\text { stakeholders }\end{array}$ & $\begin{array}{l}\text { Acts in the } \\
\text { interest of } \\
\text { legitimate } \\
\text { stakeholders }\end{array}$ & $\begin{array}{l}\text { Optimal level of engage- } \\
\text { ment with optimal level } \\
\text { number of stakeholders, } \\
\text { enhancing responsibility }\end{array}$ \\
\hline & & $\begin{array}{l}\text { B. } \\
\text { Anti-capitalism }\end{array}$ & $\begin{array}{l}\text { Excessive } \\
\text { engagement } \\
\text { with } \\
\text { stakeholders }\end{array}$ & $\begin{array}{l}\text { Acts in the } \\
\text { interest of all } \\
\text { stakeholders, } \\
\text { including } \\
\text { illegitimate }\end{array}$ & $\begin{array}{l}\text { Participation of so many } \\
\text { (including illegitimate) } \\
\text { stakeholders that the } \\
\text { purpose of the firm is } \\
\text { compromised }\end{array}$ \\
\hline \multirow{2}{*}{ 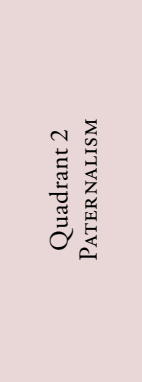 } & \multirow{2}{*}{$\begin{array}{l}\text { By separating } \\
\text { engagement from } \\
\text { responsibility, } \\
\text { we allow for the } \\
\text { possibility for a } \\
\text { company to act } \\
\text { in the interests } \\
\text { of stakeholders } \\
\text { without } \\
\text { necessarily } \\
\text { engaging with } \\
\text { them. }\end{array}$} & $\begin{array}{l}\text { C. } \\
\text { Limited } \\
\text { paternalism }\end{array}$ & $\begin{array}{l}\text { Little } \\
\text { stakeholder } \\
\text { engagement as } \\
\text { determined by } \\
\text { the company }\end{array}$ & $\begin{array}{l}\text { Acts in the } \\
\text { interest of } \\
\text { legitimate } \\
\text { stakeholders as } \\
\text { determined by } \\
\text { the company }\end{array}$ & $\begin{array}{l}\text { Acting in the perceived } \\
\text { interest of the stakeholders } \\
\text { with limited consultation }\end{array}$ \\
\hline & & $\begin{array}{l}\text { D. } \\
\text { Strong } \\
\text { paternalism }\end{array}$ & $\begin{array}{l}\text { No stakeholder } \\
\text { engagement as } \\
\text { determined by } \\
\text { the company }\end{array}$ & $\begin{array}{l}\text { Acts in the } \\
\text { interest of } \\
\text { legitimate } \\
\text { stakeholders as } \\
\text { determined by } \\
\text { the company }\end{array}$ & $\begin{array}{l}\text { Acting in the perceived } \\
\text { interest of the stakeholders } \\
\text { without consultation to } \\
\text { the point of interference } \\
\text { and reduction of liberty }\end{array}$ \\
\hline \multirow{2}{*}{ 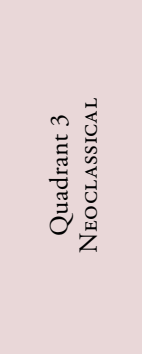 } & \multirow{2}{*}{$\begin{array}{l}\text { Where an } \\
\text { organisation has } \\
\text { little interest } \\
\text { in engaging its } \\
\text { stakeholders and } \\
\text { acts accordingly, } \\
\text { we assume an } \\
\text { economically } \\
\text { based view of the } \\
\text { firm }\end{array}$} & $\begin{array}{l}\text { E. } \\
\text { Market }\end{array}$ & $\begin{array}{l}\text { Little } \\
\text { stakeholder } \\
\text { engagement } \\
\text { in response to } \\
\text { market demand }\end{array}$ & $\begin{array}{l}\text { Does not act } \\
\text { in the interest } \\
\text { of legitimate } \\
\text { stakeholders }\end{array}$ & $\begin{array}{l}\text { Low engagement to } \\
\text { further the interests of the } \\
\text { owners, organisation and } \\
\text { stakeholders as economic } \\
\text { entities }\end{array}$ \\
\hline & & $\begin{array}{l}\text { F. } \\
\text { Illegal (outside } \\
\text { the boundary } \\
\text { of the law } \\
\text { or accepted } \\
\text { custom) }\end{array}$ & $\begin{array}{l}\text { No stakeholder } \\
\text { engagement } \\
\text { as determined } \\
\text { by agents in } \\
\text { control of the } \\
\text { company }\end{array}$ & $\begin{array}{l}\text { Does not act } \\
\text { in the interest } \\
\text { of legitimate } \\
\text { stakeholders }\end{array}$ & $\begin{array}{l}\text { Agents act in their or } \\
\text { principals interests either } \\
\text { illegally or outside moral } \\
\text { minimum norms, could } \\
\text { include fraud, theft, and } \\
\text { abuse of human rights }\end{array}$ \\
\hline \multirow{2}{*}{ 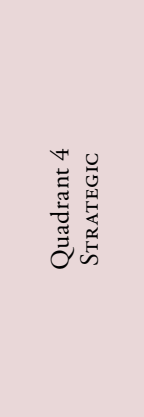 } & \multirow{2}{*}{$\begin{array}{l}\text { Where an } \\
\text { organisation } \\
\text { responds to } \\
\text { the needs of } \\
\text { stakeholders } \\
\text { with the aim } \\
\text { of furthering } \\
\text { the goals of the } \\
\text { organisation, } \\
\text { the management } \\
\text { of stakeholders } \\
\text { would be } \\
\text { understood as } \\
\text { strategic in nature }\end{array}$} & $\begin{array}{l}\text { G. } \\
\text { Reputation/ } \\
\text { Legitimacy }\end{array}$ & $\begin{array}{l}\text { Engaging with } \\
\text { legitimate } \\
\text { stakeholders } \\
\text { to further } \\
\text { shareholder } \\
\text { interests }\end{array}$ & $\begin{array}{l}\text { Appears to } \\
\text { act in the } \\
\text { interest of all } \\
\text { stakeholders }\end{array}$ & $\begin{array}{l}\text { Engaging stakeholders } \\
\text { enhances strategic } \\
\text { alignment, reputation } \\
\text { and legitimacy with } \\
\text { stakeholders }\end{array}$ \\
\hline & & $\begin{array}{l}\text { H. } \\
\text { Irresponsibility } \\
\text { (bad faith) }\end{array}$ & $\begin{array}{l}\text { Excessive } \\
\text { engagement } \\
\text { without } \\
\text { accountability } \\
\text { or responsibility } \\
\text { towards } \\
\text { stakeholders }\end{array}$ & $\begin{array}{l}\text { Appears to } \\
\text { act in the } \\
\text { interest of only } \\
\text { influential } \\
\text { stakeholders }\end{array}$ & $\begin{array}{l}\text { Engaging with } \\
\text { stakeholders under } \\
\text { deceptive conditions, } \\
\text { acting "as if" the aim } \\
\text { is to meet stakeholders' } \\
\text { interests }\end{array}$ \\
\hline
\end{tabular}


Further, the delivery of tourism products involves the interaction of a vast number of suppliers from a wide range of economic sectors, including the private, public and voluntary sector (Garrod, Fyall, Leask and Reid, 2012). Garrod et al. (2012) affirmed that stakeholder management serves as a vehicle for creating a culture in which all actors are actively involved in the development of tourism. Moreover, several authors stated that primary stakeholders must be integrated within the strategic management process (Clarkson, 1995, Reid, 2006, in Todd, Leask and Ensor, 2017) and argued that the engagement of primary stakeholders plays a critical role in tourism management (Todd et al., 2017). Furthermore, many authors argued that the concept of stakeholders is gaining importance in tourism management (Aas, Ladkin and Fletcher, 2005, Currie, Seaton and Wesley, 2009, Hall, 2007, Jamal and Getz, 1999, Mowforth and Munt, 2003, in Waligo, Clarke and Hawkins, 2013). This is due to the fact that the organisational structure of a tourism destination is regarded to be a network of multiple stakeholders (Cooper, Scott and Baggio, 2009, D'Angella and Go, 2009, in Waligo, Clarke and Hawkins, 2013) on which the quality of the experience for the visitor depends (Hawkins and Bohdanowicz, 2011, March and Wilkinson, 2009, in Waligo, Clarke and Hawkins, 2013). Scholars within the tourism sector identified the following six stakeholder categories: tourists, industry, local community, government, special interest groups and educational institutions (Butler, 1999, Getz and Timur, 2005, Hall and Lew, 1998, Markwick, 2000, Mason, 2003, in Waligo, Clarke and Hawkins, 2013). The above-mentioned stakeholders influence tourism development including tourism regulation and tourism supply and demand, human resources management, the management of tourism impacts, and tourism research (Waligo, Clarke and Hawkins, 2013). Tourism stakeholders impact directly on tourism development initiatives (Bramwell and Sharman, 2000, Getz and Timur, 2005, Hall, 2007, in Waligo, Clarke and Hawkins, 2013) and, therefore, stakeholders need to be identified, their perspectives need to be taken into account (Bramwell, Henry, Jackson and Van der Straaten, 1996, Dodds, 2007, Hardy and Beeton, 2001, in Waligo, Clarke and Hawkins, 2013), and they should be active participants in the tourism planning process (Byrd, 2003, Southgate and Sharpley, 2002, in Waligo, Clarke and Hawkins, 2013). It should be said that effective stakeholder involvement is complex and problematic due to the fragmented nature of the tourism sector (Friedman and Miles, 2006, Jamal and Getz, 1999, Mowforth and Munt, 2003, in Waligo, Clarke and Hawkins, 2013).

In the last 25 years stakeholder theory has been applied in tourism research. Recurring themes in stakeholder tourism research are tourism planning, stakeholder collaboration and sustainable development. In their influential article, Sautter and Leisen (1999) considered the application of stakeholder theory in the tourism planning process and proposed a stakeholder orientation matrix as a tool for increasing congruency across stakeholders' orientations in this way facilitating collaboration among them. Further, Sheehan and Brent Ritchie (2005) applied a stakeholder theory analysis to the study of tourism destination management organizations (DMOs), more specifically, they explored the potential of stakeholder theory as a foundation of strategic tourism destination management. They found out that DMOs that adopted a strategy encompassing the full range of stakeholders will 
be able to maximize benefits for each party, identify potential areas of cooperation and minimize stakeholders' realization of their potential to threaten.

Byrd, Bosley and Dronberger (2009) studied the differences of perceptions of tourism impacts on a rural community between four stakeholder groups namely: residents, entrepreneurs, government officials, and tourists. Their research contributed to the body of knowledge since there is limited research comparing the perceptions of different stakeholder groups in comparison to the amount of research conducted on individual stakeholder groups (Byrd et al., 2009). The authors affirmed that a clear understanding of the interests and attitudes of stakeholders is fundamental to the sustainable development of tourism. Moreover, as tourism is constantly evolving it is important for stakeholder groups to communicate with each other and be involved in the tourism development process as this can increase the overall quality of life (Byrd et al., 2009).

Lyon, Hunter-Jones and Warnaby (2017) focused on sustainable tourism and adopted a stakeholder analysis framework to analyse active stakeholder discourses of sustainable tourism development in the Waterberg Biospehre Reserve, South Africa. The authors did not undertake a full stakeholder analysis of all tourism stakeholders, rather they focused specifically upon "active stakeholders" and their influence over development outcomes. Grimble and Wellard (1997), as stated in Lyon et al. (2017: 2), defined active stakeholders as "those who affect decisions or actions, while passive stakeholders are those who are affected (either positively or negatively) by those decisions." Through their analysis, it was aimed to understand how the principles of sustainable tourism development can be put into practice more effectively. Recently, the principles of stakeholder theory have been further applied to tourism research focusing on niche markets such as ecotourism, social and religious tourism. Wondirad, Tolkach and King (2020) focused on ecotourism and integrated stakeholder theory and collaboration theory with triple-bottom-line principles in order to study stakeholder collaboration as a major factor for sustainable ecotourism development and to formulate a stakeholder collaboration framework for sustainable ecotourism. The authors pointed out that ensuring stakeholder collaboration is a challenge due to the diversity and competing interests from different stakeholders and confirmed that poor interaction and lack of cooperation among stakeholders undermine sustainable tourism development.

In 2020, Minnaert applied stakeholder theory to the field of social tourism and analysed a project conducted by the social tourism division of Tourism Flanders (Belgium) which focused on extensive stakeholder consultation through listening. The aim of the project was to collect stakeholder perspectives in order to facilitate the project's long-term success through the enhancement of the level of stakeholder involvement. Further, Lin (2021) applied stakeholder theory to a study of religious tourism since tourism development requires the involvement of all stakeholders to be successful (Lin, 2021). Lin (2021) evaluated stakeholder salience based on an analysis of the Dajia Mazu pilgrimage in Taiwan. The aim was to assess stakeholders' contributions to the pilgrimage and to gather information in order to improve planning, organizing, leading and controlling of pilgrimages and religious tourism in general. The author affirmed that religious tourism is a multistakeholder activity 
and, therefore, a multistakeholder approach to management is crucial to ensure its sustainable development.

As presented above, stakeholder theory has been applied to a variety of topics in tourism research. It can be affirmed that the application of the principles of stakeholder theory can lead to sustainable competitive advantage. Therefore, the further application of stakeholder theory in the tourism industry appears to be suitable and helpful in order to support the recovery of the sector after the Covid19 pandemic.

\section{CURRENT SITUATION OF THE TOURISM INDUSTRY AND THE VALUE OF INSTRUMENTAL STAKEHOLDER THEORY}

Due to the Covid19 pandemic, the tourism industry entered into a worldwide crisis in mid-March 2020 and international tourist arrivals decreased by $98 \%$ in May 2020 (United Nations, 2020). The pandemic threatens the long-term livelihoods of millions of people, in particular, the livelihoods of tourism-dependent workers (United Nations, 2020). According to the United Nations (2020), around 80\% of tourism enterprises worldwide are Micro, Small and Medium sized enterprises (MSMEs) with fewer than 50 employees which makes the situation even worse as these enterprises usually do not have enough savings to overcome such long-term crises (United Nations, 2020). The United Nations (2020) affirmed that this crisis is an opportunity to transform the tourism sector into a more resilient, inclusive and sustainable sector worldwide. However, this requires the application of new approaches, including partnerships and a multi-level response (United Nations, 2020). The application of instrumental stakeholder theory would achieve a multilevel response as recommended by the United Nations.

Furthermore, the recovery of the tourism sector should be founded on sustainability which will support the future resilience of the tourism sector and which depends on the sector's ability to balance all stakeholders' needs (United Nations World Tourism Organization (UNWTO), 2020). A stakeholder approach is simultaneously a sustainable approach since it takes into consideration the economic, social and environmental consequences of all stakeholders' actions.

Moreover, the UNWTO (2020) observed that the Covid19 crisis has awakened a sense of unity among tourism stakeholders worldwide. This is the perfect starting point for the application of instrumental stakeholder theory. Stakeholder theory creates a common sense of purpose and the current crisis will further support it.

The tourism industry is the main source of economic wealth in the Canary Islands as it represents over $40 \%$ of direct and indirect employment in the archipelago (Gobierno de Canarias, 2019). Currently, almost all stakeholders in the tourism sector in the Canary Islands face a very complicated situation due to the travel restrictions which have reduced tourism activity to almost cero. Both, the public and the private sector, have developed different actions in order to support the recovery of the tourism sector and all of them require the cooperation between both sectors and full support from the local community to ensure the long-term success of the 


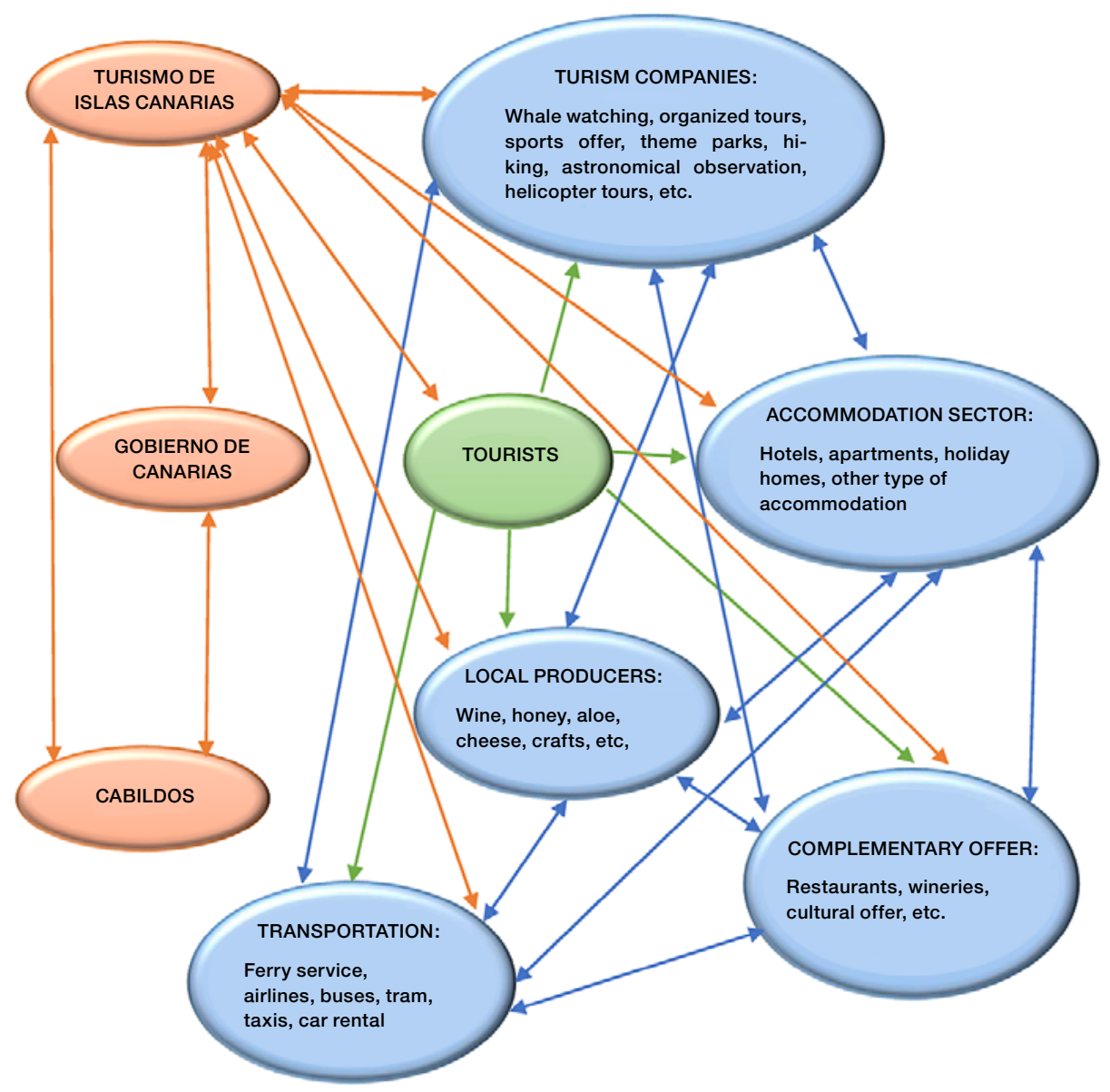

Figure 2. Possible stakeholder map of a Canarian web-based platform for the marketing and sales of the tourism offer available in the Canary Islands (own elaboration).

actions. Among the most prominent actions are, for example, an own Canarian web-based platform for the marketing and sales of the tourism offer available in the Canary Islands. It will be developed by Turismo de Islas Canarias, a public sector company. This platform aims to unify the tourism and the complementary offer for tourists which otherwise would remain unknown and it will provide up-to-date information in order to adapt the offer to the changing demand. It will connect local firms of any kind with tourism enterprises to promote local products and it will also provide visitors with information about the sustainability of their choices. The aim is to generate value for the economy and the local community, as well as, promote the sustainability of the sector and become a resilient tourism destination (El Dia, 
2021b). Another important action is to digitalize the tourism sector by rethinking and adapting processes and innovating new ones, redefining how to create added value for tourists and for the destination itself and transforming the marketing and sales of experiences (El Día, 2021a). Further, the new carrier Canarian Airways, consisting of 100\% Canarian capital, will start operations in June 2021 and will offer flights to four destinations in the Spanish mainland, two destinations in the U.K. and one in Germany (El Dia, 2021c). This project was designed many years ago but it was only the health crisis, and the following under-supply of flights to the Canary Islands, that eventually pushed investors to launch the airline. Finally, even before the pandemic the trend of remote workers choosing the Canary Islands as their base was very strong (El Día, 2020). Remote workers make use of the tourism offer but are also interested in the local culture and products. This trend has evolved to a way of life which will further develop and it is essential to take advantage of this market niche.

The examples presented above illustrate the interdependence of the tourism stakeholder network. Only as an example, and in order to demonstrate this interdependence, figure 2 shows a possible stakeholder map of a Canarian web-based platform for the marketing and sales of the tourism offer available in the Canary Islands. In order to build the stakeholder map, it is suggested to elaborate first a possible stakeholder map with the information provided by the media about the project and with information found on the websites of the public sector stakeholders. Then, semi-structured interviews should be conducted with the identified stakeholders. The information provided by the interviews will reveal further connections with other stakeholders which should then be contacted for further supplementary interviews. Snowball sampling is regarded to be the right method for establishing a definitive stakeholder map of a Canarian web-based platform for the marketing and sales of the tourism offer available in the Canary Islands.

In this example, the public sector (Turismo de Islas Canarias, Gobierno de Canarias [Government of the Canary Islands], Cabildos [Island Councils]) and the private sector are both involved and the tourists and the local community are very important stakeholders. The arrows show the connections between the stakeholders. Tourists are at the centre of the stakeholder map because the ultimate aim is to reach them in order to create value for them and for all stakeholders at the destination. Further, it should be noted that the local community is at the same time supplier and employee of the sector, as well as, local people impacting on the quality of the experience of tourists. This adds a level of complexity when engaging with them. Moreover, each stakeholder group can be divided into sub-groups, however, this level of detail would require in-depth research and this stakeholder map is meant to serve only as an example of the complexity of tourism stakeholder networks. 


\section{CONCLUSIONS}

The application of stakeholder theory to tourism research has been presented, as well as, the current situation of the tourism industry in the Canary Islands. Since tourism development requires the involvement of all stakeholders to be successful on the long-term (Lin, 2021), it can be affirmed, that the application of instrumental stakeholder theory to support the recovery of the tourism sector can be beneficial.

First of all, the tourism industry, in general, is very fragmented in nature (Friedman and Miles, 2006, Jamal and Getz, 1999, Mowforth and Munt, 2003, in Waligo, Clarke and Hawkins, 2013) and the delivery of tourism products involves the interaction of a large number of suppliers from different economics sectors (Garrod et al., 2012). Initially, some stakeholders may not appear relevant or might even be hidden to the researcher's eye. Stakeholder theory is capable to take into consideration each and every stakeholder and to connect them with each other. Second, being aware of the connections between stakeholders makes it possible to foresee the impacts that each stakeholder's action might have on the others and it makes it feasible to conceive business strategies that will not negatively impact on other stakeholders. Moreover, stakeholder theory can be applied by large organizations with thousands of employees worldwide, such as tour operators, as well as, by Micro, Small and Medium sized enterprises (MSMEs) with 1, 2 or 3 employees which are very common in the sector. Stakeholder theory is especially suitable for MSMEs since such enterprises usually know the majority of their stakeholders personally. Thus, they are able to find out about the impacts and consequences of their actions and, at the same time, they can create synergy effects and avoid trade-offs by aligning their interests with the interests of their stakeholders.

Generally, researchers focus on one actor, for example: hotels, restaurants, the government, etc., without taking into consideration the type of relationships between stakeholders and the influence or pressure they might exert on each other. A noteworthy exception is Byrd et al. (2009) who compared the perceptions of different stakeholder groups. The application of the principles of instrumental stakeholder theory makes it possible to find out about the characteristics of stakeholders' relationships with each other and how stakeholders need to cooperate in order to be successful in their respective businesses. This work would contribute to the body of knowledge by examining the relationships between all stakeholder groups instead of focusing only on one group.

Furthermore, Lyon et al. (2017) applied a stakeholder analysis framework to study sustainable tourism development. The Canary Islands are dependent on the tourism industry and aim for a sustainable recovery of the tourism industry. It is firmly believed that instrumental stakeholder theory is capable to support the sustainable tourism recovery in the Canary Islands as it offers a strategic approach which takes into account the needs of all stakeholders, promotes stakeholder collaboration and aims to create sustainable value for all actors. Moreover, a stakeholder approach supports an appropriate level of stakeholder involvement which is believed to facilitate a project's long-term success (Minnaert, 2021). Therefore, this work would contribute to the body of knowledge of sustainable tourism development. Finally, the principles 
of instrumental stakeholder theory are likely to promote competitive advantage, as well as, social welfare. Both are needed in order to overcome the current crisis in the tourism sector. Taking into consideration the fact that effective stakeholder involvement is complex due to the fragmented nature of the tourism sector (Friedman and Miles, 2006, Jamal and Getz, 1999, Mowforth and Munt, 2003, in Waligo, Clarke and Hawkins, 2013), it can be affirmed that a sustainable recovery of the tourism sector can only be achieved if all phases of stakeholder work are followed and if value creating stakeholder engagement is undertaken.

Recibido: 9 de mayo de 2021; ACEPTAdo: 10 de septiembre de 2021 


\section{BIBLIOGRAPHY}

Aas, C., Ladkin, A. \& Fletcher, J. (2005). "Stakeholder collaboration and heritage management." Annals of Tourism Research, 32(1), 28-48.

Agle, B.R., Donaldson, T., Freeman, R.E., Jensen, M.C., Mitchell, R.K. \& Wood, D.J. (2008). "Dialogue: Toward Superior Stakeholder Theory." Business Ethics Quarterly, 18(2), 153-190.

BARNEY, J.B. (2018). "Why resource-based theory's model of profit appropriation must incorporate a stakeholder perspective." Strategic Management Journal, 39(13), 3305-3325.

Bramwell, B., Henry, I., Jackson, G. \& Van der Straaten, J. (1996). Sustainable tourism management: principles and practices. Tilburg University Press.

Bramwell, B. \& Sharman, A. (2000). "Approaches to sustainable tourism planning and community participation: the case of the Hope Valley," in G. Richards, \& D. Hall (eds.), Tourism and sustainable community development (pp. 17-35). Routledge.

Butler, R.W. (1999). "Sustainable tourism: a state of the art review.” Tourism Geographies, 1(1), 7-25.

Byrd, E.T. (2003). An analysis of variables that influence stakeholder participation and support for sustainable tourism development in rural North Carolina. Unpublished manuscript.

Clarkson, M.B.E. (1995). "A stakeholder framework for analyzing and evaluating corporate social performance." Academy of Management, 20(1), 92-117.

Cooper, C., Scott, N. \& Baggio, R. (2009). "Network Position and Perceptions of Destination Stakeholder Importance." Anatolia: An International Journal of Tourism and Hospitality Research, 20(1), 33-45.

Currie, R.R., Seaton, S. \& Wesley, F. (2009). “Determining stakeholders for feasibility analysis.” Annals of Tourism Research, 36(1), 41-63.

D’Angella, F. \& Go, F.M. (2009). “Tale of two cities' collaborative tourism marketing: Towards a theory of destination stakeholder assessment." Tourism Management (1982), 30(3), 429-440.

Dodds, R. (2007). "Sustainable tourism and policy implementation: lessons from the case of Calvia, Spain." Current Issues in Tourism, 10(1), 296-322.

Donaldson, T. \& Preston, L.E. (1995). “The Stakeholder Theory of the Corporation: Concepts, Evidence, and Implications.” The Academy of Management Review, 20(1), 65-91.

EL Día (2021, 28.01.a). Raúl Domínguez: "Canarias prosperará cuando la industria turística sea capaz de ser rentable aun sin turistas.” El Día. https://www.eldia.es/economia/2021/01/28/ raul-dominguez-canarias-prosperara-industria-31863143.html.

EL DíA, E.P. (2020, 12.03.). Canarias pugna por ser destino base en Europa para los "remote workers." El Día. https://www.eldia.es/economia/2020/12/03/canarias-pugna-destinobase-europa-25901160.html.

EL DíA, E.P. (2021, 09.02.b). Canarias creará una plataforma de comercialización directa del turismo. El Día. https://www.eldia.es/canarias/2021/02/09/canarias-creara-plataformacomercializacion-directa-34335834.html.

EL Día, G.D. (2021, 10.02.c). La línea áerea de los hoteleros unirá Canarias con siete ciudades espańolas y europeas. El Dia. https://www.eldia.es/economia/2021/02/10/linea-areahoteleros-canarios-unira-34387455.html. 
Freeman, R.D., Harrison, J.S. \& Zyglidopoulos, S. (2018). Stakeholder Theory: Concepts and Strategies. Cambridge University Press.

Freeman, R.E. (1984). Strategic management: a stakeholder approach. Pitman.

Freeman, R.E. (1999). "Divergent stakeholder theory." Academy of Management Review, 24(2), 233-236.

Freeman, R., Martin, K. \& Parmar, B. (2007). “Stakeholder Capitalism.” Journal of Business Ethics, 74(4), 303-314.

Freeman, R.E., Harrison, J.S., Wicks, A.C., Parmar, B.L. \& De Colle, S. (2010). Stakeholder theory: the state of the art. Cambridge University Press.

Friedman, A.L. \& Miles, S. (2006). Stakeholders: theory and practice. Oxford University Press.

Friedman, M. (1962). Capitalism and freedom. University of Chicago Press and Phoenix Books.

Garrod, B., Fyall, A., Leask, A. \& Reid, E. (2012). "Engaging residents as stakeholders of the visitor attraction.” Tourism Management (1982), 33(5), 1159-1173.

Getz, D. \& Timur, S. (2005). “Stakeholder involvement in sustainable tourism: balancing the voices,” In W. Theobald (ed.), Global tourism (3rd ed., pp. 230-247). Butterworth Heinmann.

Gobierno de Canarias y Consejeria de Turismo, Cultura y Deportes (2019). Plan de Canarias para el Turismo 2025. Intelligent Atlas S.L.

Greenwood, M. (2007). “Stakeholder Engagement: Beyond the Myth of Corporate Responsibility.” Journal of Business Ethics, 74(4), 315-327.

Hall, C.M. (2007). Tourism planning: policies, processes and relationships. Prentice Hall.

HaLl, C.M. \& Lew, A. (eds.) (1998). Sustainable tourism: a geographical perspective. Addison Wesley Longman Ltd.

Hardy, A.L. \& Beeton, R.J.S. (2001). "Sustainable tourism or maintainable tourism: managing resources for more than average outcomes." Journal of Sustainable Tourism, 9(3), 168-192.

Hawnins, R. \& Bohdanowicz, P. (2011). Responsible hospitality: theory and practice. Goodfellow Publishers Limited.

Hendry, J. (2001). "Economic contracts versus social relationships as a foundation for normative stakeholder theory." Business Ethics: A European Review, 10(3), 223-232.

Hill, C.W.L. \& Jones, T.W. (1992). “Stakeholder-agency theory.” Journal of Management Studies, 29(2), 131-154.

Jamal, T. \& Getz, D. (1999). "Community roundtables for tourism related conflicts: the dialects of consensus and process structures." Journal of Sustainable Tourism, 7(3-4), 290-313.

Jawahar, I.M. \& Mclaughlin, G.L. (2001). “Toward a Descriptive Stakeholder Theory: An Organizational Life Cycle Approach.” The Academy of Management Review, 26(3), 397-414.

Jones, T.M., Harrison, J.S. \& Felps, W. (2018). "How applying instrumental stakeholder theory can provide sustainable competitive advantage." Academy of Management Review, 43(3), 371-391.

Jones, T.M. \& Wicks, A.C. (1999). "Convergent Stakeholder Theory.” The Academy of Management Review, 24(2), 206-221.

Jones, T.M. \& Harrison, J.S. (2019). "Sustainable wealth creation: applying instrumental stakeholder theory to the improvement of social welfare," in Harrison, J.S., Barney, J.B., Freeman, R.E. \& Phillips, R.A. (ed.), The Cambridge Handbook of Stakeholder Theory (pp. 77-96). Cambridge University Press. 
Jones, T.M., Donaldson, T., Freeman, R.E., Harrison, J.S., Leana, C.R., Mahoney, J.T. \& Pearce, J.L. (2016). "Management theory and social welfare: Contributions and challenges.” The Academy of Management Review, 41(2), 216-228.

LEE, J.H. (2015). Stakeholder work and value creation stakeholder engagement: an integrative framework. Unpublished doctoral dissertation.

Leiper, N. (1979). “The framework of tourism.” Annals of Tourism Research, 6(4), 390-407.

LIN, C. (2021). "The salience of stakeholders in religious tourism: A case study of the Dajia Mazu pilgrimage." Annals of Tourism Research, 8610.

Lyon, A., Hunter-Jones, P. \& Warnaby, G. (2017). “Are we any closer to sustainable development? Listening to active stakeholder discourses of tourism development in the Waterberg Biosphere Reserve, South Africa.” Tourism Management (1982), 61, 234-247.

March, R. \& Wilkinson, I. (2009). “Conceptual tools for evaluating tourism partnerships.” Tourism Management (1982), 30(3), 455-462.

MarkwiCK, M.C. (2000). "Golf tourism development, stakeholders, differing discourses and alternative agendas: the case of Malta." Tourism Management (1982), 21(5), 515-524.

Mason, P. (2003). Tourism impacts, planning and management. Butterworth Heinmann.

McVea, J.F. \& Freeman, R.E. (2005). "A names-and-faces approach to stakeholder management." Journal of Management Inquiry, 14(1), 57-69.

Minnaert, L. (2020). “Stakeholder stories: Exploring social tourism networks." Annals of Tourism Research, 8310.

Mitchell, R.K. \& Lee, J.H. (2019). "Stakeholder identification and its importance in the value creating system of stakeholder work," in Harrison, J.S., Barney, J.B., Freeman, R.E. \& Phillips, R.A. (ed.), The Cambridge Handbook of Stakeholder Theory (pp. 53-73). Cambridge University Press.

Mitchell, R.K., Van Buren, H.J. III, Greenwood, M. \& Freeman, R.E. (2015). "Stakeholder inclusion and accounting for stakeholders." Journal of Management Studies, 52(7), 851-877.

Mitchell, R.K., Agle, B.R. \& Wood, D.J. (1997). “Toward a Theory of Stakeholder Identification and Salience: Defining the Principle of Who and What Really Counts." The Academy of Management Review, 22(4), 853-886.

Mowforth, M. \& Munt, I. (2003). Tourism and sustainability. Routledge.

Noland, J. \& Phillips, R. (2010). "Stakeholder Engagement, Discourse Ethics and Strategic Management." International Journal of Management Reviews, 12(1), 39-49.

Peteraf, M.A. \& Barney, J.B. (2003). “Unraveling the resource-based tangle.” Managerial and Decision Economics, 24(4), 309-323.

REID, S. (2006). “Identifying social consequences of rural events." Event Management, 11(1-2), 89-98.

Sautter, E.T. \& Leisen, B. (1999). "Managing stakeholders a Tourism Planning Model.” Annals of Tourism Research, 26(2), 312-328.

Sheehan, L. \& Ritchie, J. (2005). “Destination stakeholders-Exploring identity and salience.” Annals of Tourism Research, 32(3), 711-734.

Southgate, C. \& Sharpley, R. (2002). "Tourism, development and the environment," in Sharpley, R. and Telfer, D. (ed.), Tourism and development concepts and issues (pp. 231-262). Channel View Publications. 
Theodoulidis, B., Diaz, D., Сrotto, F. \& Rancati, E. (2017). "Exploring corporate social responsibility and financial performance through stakeholder theory in the tourism industries." Tourism Management (1982), 62, 173-188.

Todd, L., Leask, A. \& Ensor, J. (2017). “Understanding primary stakeholders' multiple roles in hallmark event tourism management.” Tourism Management (1982), 59, 494-509.

United Nations (2020). "Covid-19 and transforming tourism. United Nations." https://www. unwto.org/es/news/informe-de-politicas-sobre-el-turismo-y-la-covid-19.

United Nations World Tourism Organization (2020). "One planet sustainable tourism programme: one planet vision for a responsible recovery of the tourism sector. United Nations World Tourism Organization." https://www.unwto.org/covid-19-oneplanetresponsible-recovery.

Waligo, V.M., Clarke, J. \& Hawkins, R. (2013). "Implementing sustainable tourism: A multistakeholder involvement management framework." Tourism Management (1982), 36, 342-353.

Wondirad, A., Tolkach, D. \& King, B. (2020). "Stakeholder collaboration as a major factor for sustainable ecotourism development in developing countries." Tourism Management (1982), 7810. 